\title{
Learning Clinic: Designing Problem Based Learning Student Worksheets
}

\author{
Monika Handayania), Andayani, and Jaka Warsihna \\ Program Studi S1 Pendidikan Guru Sekolah Dasar Universitas Terbuka, Banten, Indonesia \\ a)Corresponding Author: monika@ecampus.ut.ac.id
}

\begin{abstract}
In line with the implementation of the 2013 curriculum and High Order Thinking Skills (HOTS), teachers are expected to be able to design teaching materials that can facilitate critical thinking learners through investigation activities. LKPD (Lembar Kerja Peserta Didik) based on Problem Based Learning $(\mathrm{PBL})$ is one way that can encourage learners to think critically and creatively to complete learning activities that occur in everyday life. The purpose of this community service activity, teachers can design LKPD based on the PBL model and apply it in learning activities. The products resulting from activities to this community are LKPD based on the PBL model. The materials used are examples of LKPD based on the PBL model and materials on steps in PBL activities that can be aligned with the material in the 2013 curriculum. The method used is the socialization of community service and implementation activities in their respective teacher classes. The result of community service activities is LKPD based on the PBL model products made by teachers and the ease of teachers in construct LKPD based on the PBL model with learning activities to be carried out. In the conclusion of this community service activity, teachers need socialization and assistance in making teaching materials such as LKPD based on the PBL model to facilitate teachers in conducting learning activities.
\end{abstract}

Keywords: LKPD, Problem Based Learning, learning material

\section{INTRODUCTION}

The use of the 2013 curriculum requires teachers not only able to manage their learning activities but also be able to create teaching materials that are following the curriculum applied. LKPD (Lembar Kerja Peserta Didik) is one of the teaching materials that can be used by teachers to direct learners through experimental or investigation activities. (Trianto, 2010). The preparation of LKPD carried out by teachers must certainly be adjusted to the approach and learning model by the applicable curriculum. One learning model that can facilitate learners in experimental and investigation activities is the Problem Based Learning model (PBL). The PBL model prepares learners to think critically and analytically so that learners actively integrate their information and skills in solving problems (Westwood, 2008)

Not all teachers can develop teaching materials that are under the 2013 curriculum, especially the development of LKPD. This also happens to teachers at SD Islam Terpadu Nurul Iman who have never developed teaching materials that are under the 2013 curriculum based on the results of the questionnaire in the initial survey of community service activities. Based on interviews conducted with the principal, the 2013 curriculum has only been applied to SD Islam Terpadu Nurul Iman in the new academic calender 2018/2019 so that teachers still need to learn how to apply the manufacture of teaching materials under the 2013 curriculum. SD Islam Terpadu teacher Nurul Iman is very dependent on learning textbooks so that learning activities seem more textbook and less encouraging learners to obtain HOTS through research activities. The learning models that already exist in the 2013 curriculum textbooks have not been fully implemented because of the lack of teacher understanding of some of these learning models such as the PBL model.

In addition, the results of interviews with 12 teachers at SD Islam Terpadu Nurul Iman are known if teachers still differ perceptions regarding the form of LKPD. During this time, teachers thought LKPD like LKS which is commonly sold by printing office that contains some questions or tasks while the steps of learning activities are very minimal. While the real LKPD is a teaching material that contains materials, summaries, and instructions for the implementation of tasks 
following the basic agreements achieved (Prastowo, 2011). LKPD used by teachers is more given as a learning reinforcement material because learners are only encouraged to complete these tasks or questions rather than doing existing learning activities.

Based on these problems, this community service activity aims to socialize the preparation of LKPD teaching materials based on the PBL model under the 2013 curriculum. LKPD based on the PBL model is LKPD which is structured based on the steps of the PBL model among others (1) directing students to problems, (2) preparing students for learning, (3) assisting independent investigations and groups, (4) developing and presenting artifacts or evidence, and (5) analyzing and evaluating problem-solving processes (Arends, 2012). In addition to containing the steps of learning activities, LKPD is also equipped with a summary of materials and evaluation questions as additional material in encouraging learners to meet basic competencies and learning goals. Socialization activities are carried out to all teachers in SD Islam Terpadu Nurul Iman.

\section{METHOD}

Community service is carried out at Sekolah Dasar Islam Terpadu Nurul Iman Pamulang South Tangerang. The method used is by socialization and self-task. Face-to-face socialization is carried out in three meetings while independent tasks are carried out five times accompanied by a community service team. This activity is carried out within seven months starting from April to October 2019. The number of participants in this community service activity is 22 teachers of SD Islam Terpadu Nurul Iman Pamulang South Tangerang.

\section{RESULTS}

The results of these community service implementation activities teachers know the components in LKPD can construct LKPD based on the PBL model and apply LKPD based on the PBL model in their each classes. In addition, learning activities have been able to be directed according to the steps on the PBL model. Teachers are easier manage their classes and can act as facilitators. While in the lower class (such as grade 1), LKPD is less used as reference material because learners are more active in asking teachers. In its application, teachers in the lower classes have a greater role in the management of learning using LKPD based on the PBL model.

Evaluation of the results of community service activities shows that the need for continued socialization regarding the manufacture of teaching materials other than LKPD. It aims to improve the skills of teachers in the production of teaching materials and mastery of learning in the 2013 curriculum. In addition, encouraging learning activities carried out in the classroom are more active and creative to encourage learners to gain learning experience.

\section{DISCUSSION}

This community service activity, able to encourage teachers to acquire knowledge and skills in developing one of the teaching materials, namely LKPD. The creation of LKPD designed by teachers can be used as a guideline for the implementation of learning activities following the characteristics of learners. LKPD created is a learning activity sheet containing instructions and work procedures to train thinking skills following learning objectives. (Firdaus \& Wilujeng, 2018). LKPD developed by SD Islam Terpadu Nurul Iman teachers is an LKPD PBL model to encourage independent and active learning activities so that learners can gain critical thinking skills and HOTS.

Based on the observations showed that LKPD based on the PBL model makes learners' learning activities more active, especially in finding solutions, analyzing problems, and actively solving problems through activities in LKPD. This shows that LKPD can encourage learners to think critically. Just like some research results show that the use of LKPD can encourage learners to improve their ability to analyze, critical thinking skills, and learning outcomes (Kusumah, Wijaya \& Dwitagama, 2011; Nurliawaty et al., 2017) (Firdaus \& Wilujeng, 2018). 
PBL model steps in LKPD, can encourage learners to solve problems because the PBL model is structured based on problems that occur in the daily environment or environments close to learners. Some studies have also shown that the use of the PBL model can encourage learners to have critical thinking skills when encouraged to solve problems that exist in the PBL model. (Anugraheni, 2018; Kumullah et al., 2018; Winoto \& Prasetyo, 2020; Istiqomah \& Indarini, 2021). The results of interviews with teachers also explained the use of the PBL model in LKPD can encourage learners to be more critical in answering problems.

The results of several other studies also explain that the PBL model proved effective in encouraging learners to develop HOTS (Hidayati et al., 2018; Kodri Madang. Mgs Muhammad Tibrani dan Lucia Maria Santoso., 2019; Simanungkalit et al., 2019). SD Islam Terpadu Nurul Iman teachers explained that the development of HOTS in learning activities is easier by using LKPD based on the PBL model because learners are facilitated by learning devices that make it easier for learners and teachers to carry out learning activities actively. This is following the results of research conducted by Susanto \& Retnawati (2016) proving learning devices characterized by PBL models (such as LKPD-based PBL models) can effectively encourage the mastery of HOTS in learners.

\section{CONCLUSIONS And RECOMMENDATIONS}

The conclusion from the results of community service activities carried out in SD Islam Terpadu Nurul Iman is that teachers can design and apply to learn through LKPD based on the PBL models in their classrooms. SD Islam Terpadu Nurul Iman teachers can develop LKPD based on the PBL model so that the learning carried out encourages students to be more active and think critically. LKPD based on the PBL model is the beginning for teachers to be able to develop other teaching materials that are following the 2013 curriculum. The advice for community service activities in the future is to encourage teachers to be able to develop other teaching materials besides LKPD. Furthermore, the need for continued socialization is related to the development of other media to support learning activities under the 2013 curriculum.

\section{ACKNOWLEDGMENTS}

Thanks are given to 1) LPPMP Universitas Terbuka, 2) Head of Integrated Islamic Elementary School Nurul Iman, and 3) Teachers of Integrated Islamic Elementary School Nurul Iman.

\section{REFERENCES}

Anugraheni, I. (2018). Meta Analisis Model Pembelajaran Problem Based Learning dalam Meningkatkan Keterampilan Berpikir Kritis di Sekolah Dasar. Polygot, 14(1), 9-18. http://dx.doi.org/10.19166/pji.v14i1.789

Arends, R. I. (2012). Learning to teach. Mc Graw Hill.

Firdaus, M., \& Wilujeng, I. (2018). Pengembangan LKPD inkuiri terbimbing untuk meningkatkan keterampilan berpikir kritis dan hasil belajar peserta didik Developing students worksheet on guided inquiry to improve critical thinking skills and learning outcomes of students. Jurnal Inovasi Pendidikan IPA, 4(1), 26-40. http://journal.uny.ac.id/index.php/jipi

Hidayati, A. U., Retnawati, H., Matematika, P. P., \& Pascasarjana, P. (2018). Keefektifan pendekatan PBL dan pendekatan saintifik ditinjau dari HOTS dan karakter. Jurnal Pendidikan Matematika Dan Sains, 6(1), 70-82.

Istiqomah, J. Y. N., \& Indarini, E. (2021). Meta Analisis Efektivitas Model Problem Based Learning dan Problem Posing Terhadap Kemampuan Berpikir Kritis Siswa Sekolah Dasar Pada Pembelajaran Matematika. Jurnal Cendekia: Jurnal Pendidikan Matematika, 5(1), 670-681. https://doi.org/10.31004/cendekia.v5i1.553

Kodri Madang. Mgs Muhammad Tibrani dan Lucia Maria Santoso. (2019). Biodik : Jurnal IImiah Pendidikan Biologi Implementation of Problem Based Learning ( $\mathrm{PBL}$ ) Models Supported by Pedagogical Agents for Higher Order Thinking Skills ( HOTS ) in 
Learning Invertebrate Zoology Implementasi Model Problem Based Learning ( PBL ). 5(3), 262-272.

Kumullah, R., Djatmika, E. T., \& Yulianti, L. (2018). Kemampuan berpikir kritis dan penguasaan konsep siswa dengan problem based learning pada materi sifat cahaya". Jurnal Pendidikan: Teori, Penelitian, Dan Pengembangan, 3(12), 1583-1586. http://journal.um.ac.id/index.php/jptpp/

Kusumah, Wijaya \& Dwitagama, D. (2011). Mengenal Penelitian Tindakan Kelas. Indeks.

Nurliawaty, L., Mujasam, M., Yusuf, I., \& Widyaningsih, S. W. (2017). Lembar Kerja Peserta Didik (Lkpd) Berbasis Problem Solving Polya. JPI (Jurnal Pendidikan Indonesia), 6(1). https://doi.org/10.23887/jpi-undiksha.v6i1.9183

Prastowo, A. (2011). Panduan kreatif membuat bahan ajar inovatif: menciptakan metode pembelajaran yang menarik dan menyenangkan. Diva Press.

Simanungkalit, I., Utanto, Y., \& RC, A. R. (2019). The Effectiveness of PBL-Based HOTS in English Learning. Innovative Journal of $\ldots, \quad 8(2)$, 67-73. https://journal.unnes.ac.id/sju/index.php/ujet/article/view/31342

Susanto, E., \& Retnawati, H. (2016). Perangkat pembelajaran matematika bercirikan PBL untuk mengembangkan HOTS siswa SMA. Jurnal Riset Pendidikan Matematika, 3(2), 189. https://doi.org/10.21831/jrpm.v3i2.10631

Trianto, T. (2010). Mendesain model pembelajaran inovatif-progesif: konsep, landasan, dan implementasinya pada kurikulum tingkat satuan pendidikan (KTSP). Kencana.

Westwood, P. (2008). What teachers need to know about teaching method. In HortTechnology. ACER Press. https://doi.org/10.21273/horttech.22.3.410

Winoto, Y. C., \& Prasetyo, T. (2020). Efektivitas Model Problem Based Learning Dan Discovery Learning Terhadap Kemampuan Berpikir Kritis Siswa Sekolah Dasar. Jurnal Basicedu, 4(2), 228-238. https://doi.org/10.31004/basicedu.v4i2.348 


\section{ATTACHMENT}

\section{Respon Guru}

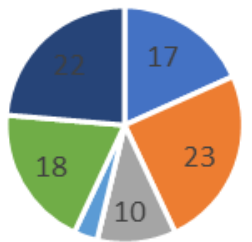

30

- Pernah membuat bahan ajar

- Mengetahui fungsi bahan ajar

- Pernah membuat LKS/LKPD

= Sering menggunakan LKS/LKPD

- Mengetahui komponen-komponen dalam pembuatan LKS

- Mengetahui LKPD

- pendapat bahan ajar dapat membantu di kelas

Figure 1. Teacher's Initial Response Questionnaire Diagram to LKPD
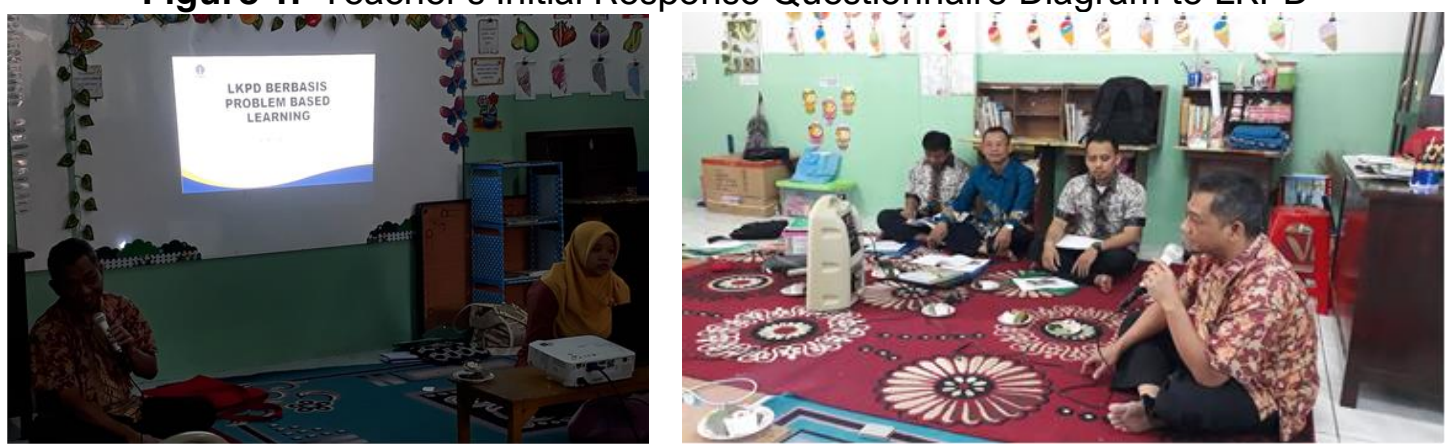

Figure 2. Documentation of Socialization/Community Service Workshop
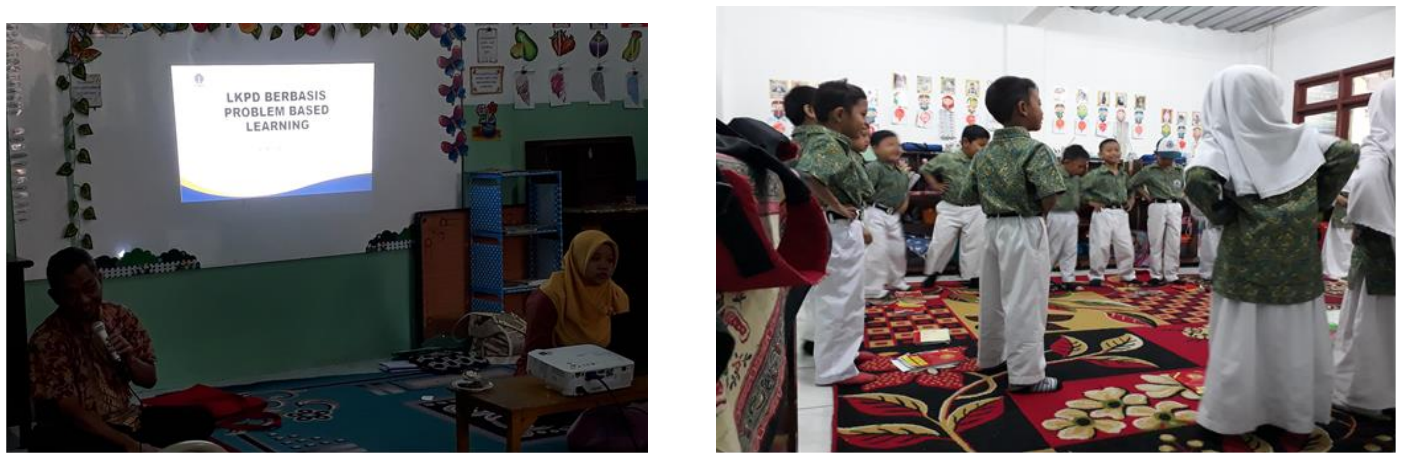

Figure 3. Documentation observation of LKPD implementation in class 